УДК 342.951

DOI https://doi.org/10.32849/2663-5313/2020.8.25

Ірина Городещька,

докт. юрид. наук, дочент,

професор кафедри політологї, права та філософії

Ніжинського державного університету імені Миколи Гоголя

\title{
КОРУПЦІОГЕННІ ФАКТОРИ \\ В СИСТЕМІ ДЕРЖАВНОГО КОНТРОЛЮ В ГАЛУЗІ ОХОРОНИ НАВКОЛИШНЬОГО ПРИРОДНОГО СЕРЕДОВИЩА
}

У статті на основі аналізу кониептуальних правових актів з питань реформування системи нагляду (контролю) в галузі охорони навколишнього природного середовища, антикорупиійних програм органів державного нагляду (контролю) в зазначеній галузі та аналітичних джерел визначено основні фактори, що сприяють корупиіі в системі державного контролю в галузі охорони навколишнього природного середовища, раціонального використання, відтворення й охорони природних ресурсів, а саме: 1) недосконалість та суперечливість вимог природоохоронного законодавства, зокрема наявність значного масиву корупиійних або дискреційних норм; 2) незадовільний рівень доступу до інформації про стан навколишнього природного середовища та його об'єкти, відсутність автоматизованих процесів моніторингу довкілля, закритість інформації про результати контролю, що створює можливості для маніпулювання даними; 3) нечіткість або відсутність адміністративних прочедур, спрямованих на здійснення певних прав або виконання обов'язків фізичними та юридичними особами, що створює можливості для державного органу (посадової особи) невмотивовано змінювати хід адміністративної процедури, діяти на власний розсуд, приймаючи рішення; 4) дублювання функиій контролюючих органів в частині контролю і нагляду, що призводить до збільшення тиску на суб'єктів господарювання та створення умов, сприятливих для вимагання хабара; 5) широкі дискреційні повноваження посадових осіб, уповноважених на здійснення контрольно-наглядових функцій, та низький рівень оплати їхньої прачі, що створює умови, сприятливі для можливості зловживання ними своӥми повноваженнями під час здійснення заходів державного нагляду (контролю); 6) неефективність інституту громадських інспекторів з охорони довкілля; 7) недостатній рівень обізнаності серед керівників та співробітників контролюючих органів з питань практичного застосування антикорупиійного законодавства; 8) низький рівень профілактичної роботи із запобігання проявам корупційних правопорушень та правопорушень, пов'язаних з корупцією, відсутність контролю з боку керівництва за діями підлеглих осіб.

Зроблено висновок, що в умовах поглиблення екологічної кризи підвищення рівня ефективності функиіонування системи державного контролю в галузі охорони навколишнього природного середовища має бути одним із першочергових завдань держави. Реалізачія останнього в умовах нестабільної економічної та політичної ситуачії в країні, надмірного динамізму права й низького рівня екологоправової культури неможлива без визначення, дослідження $i$, головне, урахування факторів, які сприяють корупиї у здійсненні органами влади державного контролю в зазначеній галузі, що, у свою чергу, дозволить мінімізувати корупиійні ризики.

Ключові слова: корупціогенні фактори, корупційні ризики, державний орган, державний контроль, галузь охорони навколишнього природного середовища.

Постановка проблеми. В умовах поглиблення екологічної кризи дедалі гостріше постає питання щодо створення дієвого механізму забезпечення захисту довкілля. Разом із тим відсутність результатів у виконанні заходів, передбачених Концепцією реформування системи державного нагляду (контролю) у сфері охорони навколишнього природного середовища, схваленою розпорядженням Кабінету Міністрів
України 31 травня 2017 р. № 616-р, а також низка непослідовних дій щодо структурних і функціональних змін системи державного нагляду (контролю) в зазначеній сфері свідчить про стагнацію реформи та необхідність детального планування іï реалізації. Крім того, корупційні прояви у сфері дозвільної та контролюючої діяльності органів державної влади в галузі охорони навколишнього природного середовища набули загрозливих 
масштабів, що, у свою чергу, потребує ухвалення нових засад державної антикорупційної політики, які визначатимуть першочергові заходи із запобігання та протидії корупції на найближчі роки. Наразі відсутність антикорупційної стратегії, дієвих антикорупційних програм органів виконавчої влади, що здійснюють функції нагляду (контролю) у сфері охорони навколишнього природного середовища, раціонального використання, відтворення і охорони природних ресурсів, не сприяє створенню ефективної системи запобігання і протидії корупції в зазначеній галузі, а також гальмує впровадження ефективних механізмів зниження корупційних ризиків у здійсненні органами влади державного контролю у природоохоронній сфері.

Аналіз останніх досліджень і публікацій. Вагомий внесок у дослідження теоретикоправових проблем державного контролю зробили такі українські вчені-адміністративісти, як В. Б. Авер'янов, О. Ф. Андрійко, Ю. П. Битяк, В. М. Гаращук, Т. О. Коломоєць, В. К. Колпаков, В. І. Курило, Н. В. Лебідь, С. В. Пєтков, О. Ю. Піддубний, О. П. Світличний, С. Г. Стеценко, М. М. Тищенко та ін. Різні аспекти державного контролю та нагляду у сферах природокористування й охорони навколишнього природного середовища досліджувалися у працях таких науковців, як В. І. Андрейцев, Г. І. Балюк, А. П. Гетьман, I. В. Гиренко, О. В. Головкін, Н. І. Золотарьова, Т. С. Кичилюк, В. І. Книш, В. В. Костицький, М. В. Краснова, Ю. О. Легеза, В. В. Пахомов, О. Ю. Піддубний, К. А. Рябець, О. О. Сурілова, В. М. Тюн, Ю. С. Шемшученко, М. В. Шульга та ін. Разом із тим проблематика мінімізації корупційних ризиків, властивих нинішній системі державного контролю в галузі охорони навколишнього природного середовища, $€$ надзвичайно актуальною.

Метою статті $є$ дослідження та визначення основних факторів, які сприяють корупції у здійсненні органами влади державного контролю в галузі охорони навколишнього природного середовища, раціонального використання, відтворення і охорони природних ресурсів.

Виклад основного матеріалу. Відповідно до ч. 2 ст. 35 Закону України «Про охорону навколишнього природного середовища» державному контролю підлягають використання і охорона земель, надр, поверхневих і підземних вод, атмосферного повітря, лісів та іншої рослинності, тваринного світу, морського середовища та природних ресурсів територіальних вод, континентального шельфу та виключної (морської) еконо- мічної зони України, природних територій та об'єктів, що підлягають особливій охороні, стан навколишнього природного середовища, а також дотримання заходів біологічної і генетичної безпеки щодо біологічних об'єктів навколишнього природного середовища при створенні, дослідженні та практичному використанні генетично модифікованих організмів у відкритій системі [1].

Сфера використання природних ресурсів в Україні, на думку Ю. О. Легези, залишається однією 3 найбільш корумпованих сфер публічного управління. У сучасних умовах в Україні тривалий час функціонуе безліч корумпованих схем обігу масштабних обсягів лісових ресурсів, корисних копалин, риби і морських тварин, земельних ділянок, інших природних ресурсів та навіть відходів [2, c. 157-158]

Попри значну кількість контролюючих органів, рівень функціонування системи державного контролю в галузі охорони навколишнього природного середовища $є$ незадовільним, про що свідчить аналіз джерел, присвячених діагностиці ефективності реалізації національної екологічної політики [3], а також концептуальних правових актів 3 питань реформування системи нагляду (контролю) в зазначеній сфері. Так, розпорядженням Кабінету Міністрів України від 31 травня 2017 р. № 616-р схвалена «Концепція реформування системи державного нагляду (контролю) у сфері охорони навколишнього природного середовища», у якій наголошується на: дискредитації та фактичному руйнуванні системи державного нагляду (контролю) у сфері охорони навколишнього природного середовища лобістами великого промислового і аграрного бізнесу; низькому кваліфікаційному рівні державних інспекторів 3 охорони навколишнього природного середовища, що є наслідком низької заробітної плати, застарілої матеріально-технічної та лабораторної бази, недостатнього обсягу фінансування, високого рівня корупції, непрозорої системи прийняття рішень щодо порушників природоохоронного законодавства; низькій ефективності та недієздатності Державної екологічної інспекції України; дублюванні наглядових (контрольних) функцій центральними органами виконавчої влади та відсутності єдиного підходу до виконання функцій; відсутності прозорого механізму проведення моніторингу стану навколишнього природного середовища та доступу до великої кількості екологічних даних, що повинні бути відкритими; епізодичній участі громадських інспекторів у заходах Державної екологічної інспекції України з нагляду (контролю) [4]. 
На наш погляд, є підстави виокремити такі головні групи причин незадовільного рівня функціонування системи державного контролю в галузі охорони навколишнього природного середовища: структурно-функиіонального характеру (недосконала організаційна структура суб'єктів контролю, дублювання функцій з нагляду (контролю) центральними органами виконавчої влади, відсутність належної координації їхньої діяльності щодо здійснення моніторингу довкілля та гармонізації законодавства); інформаиійного характеру (відсутність ефективного державного моніторингу стану довкілля, єдиних електронних реєстрів природних ресурсів, незадовільний рівень інформаційного обміну та доступу до інформації про стан навколишнього природного середовища та його об'єкти); ресурсно-забезпечувального характеру (низький рівень фінансового, технічного та кадрового потенціалу) [5, с. 196; 6, с. 79]

Відповідно до ст. 19 Закону України «Про запобігання корупції» від 14 жовтня 2014 р. № 1700-VII та низки підзаконних нормативно-правових актів з питань запобігання корупції, державні органи приймають антикорупційні програми, які затверджуються рішенням Національного агентства 3 питань запобігання корупції. Антикорупційні програми повинні передбачати: визначення засад загальної відомчої політики щодо запобігання та протидії корупції у відповідній сфері, заходи з їх реалізації, а також 3 виконання антикорупційної стратегії та державної антикорупційної програми; оцінку корупційних ризиків у діяльності органу, установи, організації, причини, що ï породжують та умови, що їм сприяють; заходи щодо усунення виявлених корупційних ризиків, осіб, відповідальних за їх виконання, строки та необхідні ресурси; процедури щодо моніторингу, оцінки виконання та періодичного перегляду програм та ін. [7]. Зокрема, аналіз антикорупційних програм органів державного нагляду (контролю) у галузі охорони навколишнього природного середовища, раціонального використання, відтворення і охорони природних ресурсів вказує на те, що загальні засади відомчої політики зазначених органів у сфері запобігання та виявлення корупції спрямовані на: широке залучення громадськості до процесів контролю за дотриманням вимог природоохоронного законодавства, аналізу проектів нормативно-правових актів на предмет дискреційних повноважень, прийняття управлінських та організаційно-розпорядчих рішень відповідними органами з метою забезпечення відкритості та прозорості як передумови належного доступу громадськості до інформації та результатів їхньої діяльності; дерегуляцію повноважень контролюючих органів та тісну співпрацю із територіальними громадами у процесі здійсненні повноважень у природоохоронній сфері; безумовну та невідворотну реалізацію антикорупційного законодавства та ін. [8; 9; 10].

Оцінка корупційних ризиків здійснюється з урахуванням особливостей напрямів діяльності органів державного нагляду (контролю) у галузі охорони навколишнього природного середовища, внутрішніх та зовнішніх чинників, які сприяють вчиненню корупційних або пов'язаних із корупцією правопорушень. Аналіз звітів за результатами проведення оцінки корупційних ризиків у діяльності органів державного нагляду (контролю) у галузі охорони навколишнього природного середовища, раціонального використання, відтворення і охорони природних ресурсів вказує на те, що найбільш поширеними $є$ корупційні ризики, пов'язані: зі здійсненням контрольно-наглядових функцій; з управлінням персоналом; зі здійсненням організаційної діяльності; зі здійсненням претензійної роботи; з підготовкою нормативно-правових актів; з управлінням фінансами; з публічними закупівлями; із забезпеченням відкритості та прозорості в діяльності контролюючих органів, залучення громадськості до здійснення антикорупційних заходів; з проведенням конкурсів на зайняття вакантних посад державної служби [11; 12].

Враховуючи викладене вище, до основних факторів, що сприяють корупції в системі державного контролю в галузі охорони навколишнього природного середовища, раціонального використання, відтворення і охорони природних ресурсів, слід віднести:

1) недосконалість та суперечливість вимог природоохоронного законодавства, зокрема наявність значного масиву корупційних або дискреційних норм. На існуванні недоліків нормативно-правових актів, якими регулюються повноваження, організація i порядок державного контролю та нагляду у сфері природоохоронного законодавства, наголошено в низці наукових та аналітичних джерел. Серед останніх слід виділити грунтовне дослідження, проведене експертами Фундації «Відкрите суспільство» у рамках Проекту «Відкритий доступ (Open Access)» (2019р.), присвячене аналізу нормативноправового регулювання й адміністративних процедур у сфері охорони навколишнього природного середовища, виявленню зон підвищених корупційних ризиків і негативних впливів на конкуренцію та відповідних факторів і індикаторів їх прояву [13]; 
2) незадовільний рівень доступу до інформації про стан навколишнього природного середовища та його об'єкти, відсутність автоматизованих процесів моніторингу довкілля, закритість інформації про результати контролю, що створює можливості для маніпулювання даними. Нині представниками експертного середовища розроблені та запропоновані рекомендації, виконання яких забезпечить таке: автоматизовані процеси моніторингу стану довкілля; публічність даних моніторингу стану довкілля (що убезпечить від прямого фактору залучення людини до визначення стану забруднення довкілля та можливості маніпулювання даними); повну та своєчасну інформацію від усіх «суб'єктів впливу» у сфері охорони навколишнього природного середовища; оперативні прогнози змін навколишнього природного середовища в екологічній сфері [14, с. 10];

3) нечіткість або відсутність адміністративних процедур, спрямованих на здійснення певних прав або виконання обов'язків фізичними та юридичними особами, що створює можливості для державного органу (посадової особи) невмотивовано змінювати хід адміністративної процедури, діяти на власний розсуд, приймаючи рішення. Нині корупційні ризики мають місце у таких сферах: набуття права користування надрами; розрахунок, розподіл та використання екологічного податку; набуття права на спеціальне водокористування; набуття права проведення робіт на землях водного фонду; здійснення оцінки впливу на довкілля; здійснення державної реєстрації (перереєстрації) пестицидів і агрохімікатів; встановлення лімітів використання природних ресурсів; набуття права на спеціальне використання природних ресурсів у межах територій та об'єктів природно-заповідного фонду; набуття права здійснення господарської діяльності при поводженні з генетичномодифікованими організмами; набуття права спеціального використання об'єктів тваринного світу, природних рослинних ресурсів; набуття права на спеціальне використання (добування, збирання) об'єктів Червоної книги України; виділення лісових ділянок для довгострокового тимчасового користування лісами; набуття права на спеціальне використання лісових ресурсів шляхом одержання спеціального дозволу; застосування санкцій за порушення лісового законодавства; набуття права здійснення операцій у сфері поводження з відходами [13, с. 48-68];

4) дублювання функцій контролюючих органів у частині контролю і нагляду, що призводить до збільшення тиску на суб'єктів господарювання та створення умов, сприят- ливих для вимагання хабара. На зазначеній проблемі нами неодноразово наголошувалось у попередніх дослідженнях [5; 6], крім того, рекомендації щодо можливих шляхів їі вирішення надані у низці наукових та аналітичних джерел [13; 14, с. 10-15];

5) широкі дискреційні повноваження посадових осіб, уповноважених на здійснення контрольно-наглядових функцій та низький рівень оплати їх праці, що створює умови, сприятливі для можливості зловживання ними своїми повноваженнями під час здійснення заходів державного нагляду (контролю) дотримання вимог природоохоронного законодавства. Варто наголосити, що проблема нечіткого визначення функцій, прав, обов’язків і відповідальності державних органів (посадових осіб) має бути вирішена у першу чергу, зокрема, шляхом детальної регламентації компетенції суб'єктів, що здійснюють державне управління та регулювання в галузі охорони навколишнього природного середовища нормативно-правовими актами, системної погодженості останніх, їх чіткості, конкретності і зрозумілості для виконавців;

6) неефективність інституту громадських інспекторів з охорони довкілля. Аналіз інформації про діяльність громадських інспекторів 3 охорони довкілля свідчить про відсутність результативності їхньої роботи. При цьому слід констатувати, що мають місце випадки зловживання наданими інспекторам правами, зокрема, щодо складення актів перевірок і протоколів про адміністративні правопорушення, що використовується досить часто для тиску на громадян і підприємців з метою отримання вигоди;

7) недостатній рівень обізнаності серед керівників та співробітників контролюючих органів з питань практичного застосування антикорупційного законодавства;

8) низький рівень профілактичної роботи із запобігання проявам корупційних правопорушень та правопорушень, пов'язаних із корупцією, відсутність контролю з боку керівництва за діями підлеглих осіб [9; 11; 12].

\section{Висновки}

Підсумовуючи дослідження, необхідно зазначити, що в умовах поглиблення екологічної кризи підвищення рівня ефективності функціонування системи державного контролю в галузі охорони навколишнього природного середовища, раціонального використання, відтворення і охорони природних ресурсів має бути одним із першочергових завдань держави. При цьому його реалізація в умовах нестабільної економічної та політичної ситуації в країні, надмірного динамізму права й низького рівня еколого-пра- 
вової культури неможлива без визначення, дослідження i, головне, урахування факторів, які сприяють корупції у здійсненні органами влади державного контролю в зазначеній галузі, що, у свою чергу, дозволить мінімізувати корупційні ризики.

\section{Список використаних джерел:}

1. Про охорону навколишнього природного середовища : Закон України від 25.06.1991 р. № 1264-XII. Дата оновлення: 07.06.2020. URL http://zakon5.rada.gov.ua/laws/show/1264-12 (дата звернення: 27.07.2020)

2. Легеза Ю. О. Адміністративно-правові засади публічного управління у сфері використання природних ресурсів: дис. ... д-ра. юрид. наук: 12.00.07 / Держ. ВНЗ Запоріз. нац. ун-т М-ва освіти і науки України. Запоріжжя, 2018. 512 с.

3. Оцінка виконання Стратегії державної екологічної політики України на період до 2020 року та Національного плану дій 3 охорони навколишнього природного середовища на 2011-2015 роки / Офіційний сайт Міністерства екології та природних ресурсів України. URL: https://menr.gov.ua/news/29270.html (дата звернення: 19.12.2019).

4. Про схвалення Концепції реформування системи державного нагляду (контролю) у сфері охорони навколишнього природного середовища : розпорядження Кабінету Міністрів України від 31.05.2017 р. № 616-p. URL: http://zakon2.rada.gov.ua/laws/show/616-2017\% D1\%80 (дата звернення: 27.07.2020).

5. Городецька I. А. Адміністративно-правове регулювання охорони, використання і відтворення тваринного світу України : дис. ... д-ра. юрид. наук: 12.00.07 / Нац. ун-т біоресурсів і природокористування України, 2019. 474 с

6. Городецька I. А. Державний контроль у галузі охорони, використання й відтворення тваринного світу в Україні: сучасний стан і напрями реформування. Право і суспільство. 2018. № 2. Ч. 3. С. $74-80$.

7. Про запобігання корупції : Закон України від 14.10.2014 р. № 1700-VII. Дата оновлення:
23.07.2020. URL: https://zakon.rada.gov.ua/laws/ show/1700-18\#n246 (дата звернення: 27.07.2020).

8. Антикорупційна програма Державної екологічної інспекції України // Офіційний вебпортал Державної екологічної інспекції України. URL: https://www.dei.gov.ua/posts/132 (дата звернення: 27.07.2020).

9. Антикорупційна програма Державного агентства рибного господарства України на 2019-2020 роки // Офіційний веб-сайт Державного агентства рибного господарства України. URL: https://darg.gov.ua/files/11/03_30_kor19. pdf (дата звернення: 27.07.2020).

10. Антикорупційна програма Державного агентства лісових ресурсів України на 2018-2020 роки // Офіційний веб-сайт Державного агентства лісових ресурсів України. URL: https://drive.google.com/file/d/1Sh-ZJ8Nt Wz7Ed2GiH0wzlldyLtFg0A8-/view (дата звернення: 27.07.2020).

11. Звіт за результатами проведення оцінки корупційних ризиків у Державній екологічній інспекції України // Офіційний веб-портал Державної екологічної інспекції України. URL: https://www.dei.gov.ua/posts/133 (дата звернення: 27.07.2020).

12. Звіт за результатами оцінки корупційних ризиків у діяльності Державного агентства лісових ресурсів України // Офіційний веб-сайт Державного агентства лісових ресурсів України. URL: https://drive.google.com/file/d/1ShZJ8NtWz7Ed2GiH0wzlldyLtFg0A8-/view (дата звернення: 27.07.2020).

13. Глібіщук Я., Шевченко Л. Зони підвищених корупційних ризиків і негативних впливів на конкуренцію, зумовлені недоліками нормативно-правового регулювання у сфері охорони навколишнього природного середовища та недоступністю екологічної інформації і даних з питань довкілля. Київ, 2019. 73 с.

14. Механізми мінімізації корупції в реалізації державного контролю та нагляду за довкіллям: аналітична записка. 2018. 37 с. // USAID ВзаємоДія. URL: https://rpr.org.ua/wp-content/ uploads/2018/04/Analytical-note_Ecology-Final. pdf (дата звернення: 27.07.2020).

\section{Iryna Horodetska. Corruption factors in the system of state control in the area of protection} of natural environment

The article, based on the analysis of conceptual legal acts on reforming the system of supervision (control) in the area of protection of natural environment, anti-corruption programs of state supervision (control) in this area and analytical sources, identifies the main factors contributing to corruption in the system of state control in the area of protection of natural environment, rational use, reproduction and protection of natural resources, namely: 1) imperfection and inconsistency of the requirements of environmental legislation, in particular the presence of a significant array of corruptive or discretionary norms; 2) unsatisfactory level of access to information about the state of the environment and its objects, the lack of automated environmental monitoring processes, the secrecy of information about the results of control, which creates opportunities for data manipulation; 3 ) vagueness or absence of administrative procedures aimed at exercising certain rights or execution of obligations of individuals and legal entities, which creates opportunities for the state body (official) to unjustifiably change the course of the administrative procedure, to act at its own discretion in making decisions; 4) duplication of functions of controlling bodies in terms of control and supervision, which leads to increased pressure on business entities and the creation of conditions conducive to extortion; 5) wide 
discretionary powers of officials authorized to perform control and supervisory functions and low level of remuneration of their work, which creates conditions favorable for the possibility of abuse of their powers in the implementation of measures of state supervision (control); 6) inefficiency of the institute of public inspectors for environmental protection; 7) insufficient level of awareness among managers and employees of regulatory bodies on the practical application of anti-corruption legislation; 8) low level of preventive work in the direction of prevention of corruption and corruption-related offenses, lack of control by management over the actions of subordinates. It is concluded that in the conditions of deepening of ecological crisis, increase of the level of efficiency of functioning of system of the state control in the area of protection of natural environment has to be one of priority tasks of the state. Implementation of the latter in conditions of an unstable economic and political situation in the country, excessive dynamism of law and low level of environmental and legal culture is impossible without identifying, researching, and, most importantly, taking into account factors that contribute to corruption in government control in this area, which, in turn, will minimize corruption risks.

Key words: corruption factors, corruption risks, state body, state control, the area of protection of natural environment. 